\title{
Habitus of social security in the lifestyles of rural families: the case of the São Miguel do Anta and Piranga municipalities in Zona da Mata Mineira, Brazil
}

\author{
Vanessa Aparecida Moreira de Barros $^{1}$ Ana Louise de Carvalho Fiúza \\ Neide Maria de Almeida Pinto ${ }^{3}$
}

${ }^{1}$ Doutorado em Extensão Rural, Departamento de Economia Rural, Universidade Federal de Viçosa (UFV), 36570-000, Viçosa, MG, Brasil. E-mail: vanessa.barros@ufv.br. "Corresponding author.

${ }^{2}$ Programa de Pós-graduação em Extensão Rural, Universidade Federal de Viçosa (UFV), Viçosa, MG, Brasil.

${ }^{3}$ Programa de Pós-graduação em Economia Doméstica, Universidade Federal de Viçosa (UFV), Viçosa, MG, Brasil.

\begin{abstract}
The universalization of the right to social security for rural producers and rural workers is a recent victory for Brazilian society. The implementation of this benefit began in the early 1990s. This article aimed to analyze the effects of rural social security on the lifestyle of families with retirees. The research was conducted in two small municipalities with agricultural economies from Zona da Mata Mineira region. The research used cross-sectional data collection procedures by applying a survey with open and closed-ended questions about consumption and living. The research sample was representative of the study population, comprising 117 rural elderly people, 64 from Piranga City and 53 from São Miguel do Anta City. Data obtained were categorized, analyzed and tested using Statistical Package for Social Sciences (SPSS) software. The survey results highlighted routine behavior and a predisposition to act based on a long term planning system, supported by the certainty of receiving the pension. Planned and long-term investments became a reality, including home improvement projects and acquisition of durable goods. Concerns about immediate family maintenance gave way to a perspective based on future planning.
\end{abstract}

Key words: rural retirement, rustic habitus, pension habitus, ways of life and consumption.

O "habitus previdenciário" na vida das famílias rurais: o caso dos municípios de São Miguel do Anta e Piranga na Zona da Mata Mineira

RESUMO: A universalização do direito à previdência social rural para os produtores e trabalhadores rurais é uma conquista recente da sociedade brasileira. A implementação deste beneficio se deu no início da década de noventa. O objetivo deste artigo foi analisar os efeitos da previdência social rural no modo de vida das famílias com aposentados. A investigação foi realizada em dois pequenos municípios de economia agrícola da região da Zona da Mata Mineira. A pesquisa utilizou procedimentos cross-sectionais de coleta de dados, através da aplicação de um survey com perguntas abertas e fechadas voltadas para aspectos relativos ao consumo e à moradia. A amostra da pesquisa foi representativa da população estudada, tendo sido constituida por 117 idosos rurais: 64 do município de Piranga e 53 de São Miguel do Anta. Os dados foram categorizados, analisados e testados por meio do software Statistical Package for Social Sciences (SPSS). Os resultados da pesquisa evidenciaram uma rotina e uma predisposição para agir marcada pelo planejamento em relação ao tempo futuro, a qual se apoiava na segurança do recebimento mensal da aposentadoria. Investimentos planejados à longo prazo mostraram-se presentes nos projetos de reforma da casa e na compra de bens duráveis. A preocupação com as questões imediatas de sustento da família cedeu espaço para a perspectiva de planejamento futuro.

Palavras-chave: aposentadoria rural, habitus rústico, habitus previdenciário, modos de vida e consumo.

\section{INTRODUCTION}

This article aimed to assess whether lifestyles of elderly people were changed after they began to receive a rural retirement income. Economic support of this population is a topic that has been widely discussed since the 1990s, when elderly people of both genders began to have access to social security. Rural pensions brought changes into municipality dynamics, into the houses structures and into the lifestyles of entire families. Stability from receiving this benefit enabled rural people to plan future expenses and to finance home improvements, such as through acquisition of durable goods and expenditures related to basic family needs (e.g., food, transport, health and education for children and grandchildren). Despite all the changes facilitated by rural pensions and the impact they have had on the lifestyles of rural people, few studies on this topic have been conducted, which demonstrated the innovative character of this article.

Promulgation of Laws 8,212 and 8,213 , which were added to the Brazilian Constitution of 1988, has contributed broadly to the universalization of rural workers' rights. After the implementation of these two laws in 1992, rural pesions for elderly and poor people of both genders became available as long as they could prove they had been farmers, agricultural partners, 
sharecroppers, farming tenants, prospectors or artisan fishers. Access to social rights by rural population has been one of the most important causes of social leveling out between urban and rural inhabitants and has also created profound changes in the lives of rural families. Receiving a regular monthly rural retirement income has institutionalized what could be characterized as a new habitus (BRUMER, 2002).

According to BOURDIEU (1980), habitus has a role as the "generating and organizing principles of practices and representations." According to DUBAR's (2005) interpretation, habitus is the practices generating structure. The author emphasized that habitus must not be conceived as "the product of a social condition of origin, but mainly, is focused on the social history of the descendants" (DUBAR, 2005, p. 80). As per Dubar's (2005) interpretation of BOURDIEU's (1980) research, habitus is not constituted primarily by a cultural reproduction of the social group of origin but has an inclination toward family history. In other words, receiving a regular rural retirement income would allow the emergence of life projects focused on family's future. Therefore, BOURDIEU (1980) presented two points of view associated to the habitus concept. He characterized it as being directed related to the preservation of the group "in its being"; but conversely, he stated that it is in harmony with transformations emerging from the material conditions of existence and with the subjective interpretations that individuals forge from the surrounding world.

Based on BOURDIEU's (1980) concept of habitus, Souza (2006) proposed the concept of rustic habitus applied to contexts of late modernity-such as the one experienced in Brazil that are characterized by patterns of inequality that generate sub-citizens. According to SOUZA (2006), rustic habitus refers to practices situated below the threshold of primary habitus; which expresses the marginalization of individuals prior to the modernization process. This process would lead sub-citizens into the periphery of society because of a lack of resources, opportunities and "social acknowledgement". In contrast, secondary habitus is characterized by the social acknowledgement of a person, highlighted by access to social and economic rights.

Applying SOUZA's (2006) concept to the situation experienced by the rural elderly, one could associate secondary habitus to the process of institutionalizing access to rural social security in the lives of families with retired individuals. By receiving this benefit, most families with retirees could afford the possibility of restructuring the concepts they had previously held. This was important for disruption of old behaviors that had been based on satisfying immediate needs. Consequently, social security habitus is similar to secondary habitus since it allows rural families with retirees to become willing to act in a way that reveals they have overcome uncertainties regarding their future enable the development of practices focused on planning medium and long-term actions. The expression "social security habitus" is intended to characterize the predisposition to act according to the incorporation of certain everyday practices, which is similar to BOUDIEU's (2008) characterization. The right to receive a rural pension has introduced practices that have been incorporated into the lifestyles of elderly people. The topics below detail this process.

Studies by DELGADO \& CARDOSO Jr. (2000) and BELTRÃO et al. (2005) have indicated that in rural societies in Brazil, monthly pension payments have introduced more economic stability into the lives of families with elderly dependents. The security provided by monthly pension payments has created the perspective of investments aiming the achievement of medium and long-term goals that can be attained using installment plans with fixed monthly amounts. Before the institutionalization of this social security habitus, a rustic one characterized for being self-sufficient was typical in farming societies. CANDIDO (2003) conducted a study on traditional rural society in the state of São Paulo in the mid20th century. His study drew attention to the fact that rural people from São Paulo elaborated their own techniques, based on their own knowledge to explore the natural resources around them.

However, the influence of urbanindustrial society has contributed to the incorporation of habits that are different from those typical of the traditional structure. This fact has forced farmers to leave their homes and migrate to the city and has also resulted in the emergence of new lifestyles among those who have stayed in the countryside. The monetarization of economic life has permeated the rural environment and it is associated with the acquisition of new consumption patterns among farmers. Besides, it has contributed to intensifying their bonds with urban life. The urban influence has introduced new habits that contributed to transforming their ways 
of living, working and eating. FIÚZA et al. (2014) pointed out a similar situation in villages in Minho, Portugal's northwest. However, in the Portuguese case, the rustic habitus of farmers from Minho was overcome by the growth of pluriactivity from the 1990s onward, with the intensification of the integration process into the European Union.

The present article aimed to analyze more specifically the lifestyles of rural families with retirees and reveals a changing process that follows the introduction of social security payments in their lives. It analyzes whether rural retirement income has created in these families a social security habitus characterized by new perspectives and practices incorporated into their lives.

\section{MATERIALS AND METHODS}

Procedures with a quantitative approach were used in this study. Two municipalities were selected: Piranga and São Miguel do Anta, both of them part of the micro-region of Viçosa in Zona da Mata Mineira. This area is characterized by its agricultural economy, which is supported by the cultivation and commercialization of coffee. Both municipalities have strong rural populations and, in fact, Piranga's rural population is twice bigger than its urban population (IBGE, 2015).

To define the sample, the aim was to identify families living in the countryside and receiving a rural pension. Therefore, registration data provided by the Family Health Programs (PSFs) of the Departments of Health in both municipalities were used. It was possible to register 833 and 257 elderly individuals at the PSFs in Piranga and São Miguel do Anta, respectively. Sample sizes were calculated using the finite proportion formula (BOLFARINE \& BUSSAB, 2005). Sample from Piranga comprised 63 interviewees randomly selected from the registered 833 individuals. The sample from São Miguel do Anta comprised 54 interviewees randomly selected from the 257 registered individuals. As a result, the total sample included 117 individuals.

The interviews were structured using open and closed-ended questions that aimed to investigate the consumption and investment practices of families with retirees before and after receiving the benefit. This step included mapping of the number of household appliances acquired using other financial resources before retirement and the amount of goods acquired using the pension payment after retirement. After collecting the data, responses were tabulated and the version 20.0 of the statistical program Statistical Package for Social Sciences (SPSS) was used to analyze the variables. Finally, per capita data from Piranga and São Miguel do Anta were used along with the censuses of 1991, 2000 and 2010 to verify the average value of per capita income in both municipalities and to show the economic context, helping reach an understanding of the social security's impact for this population.

\section{RESULTS AND DISCUSSION}

The demographic dynamic's analyzes of the two small municipalities under study, reveals that the rural populations had decreased since the 1970s, like happens in most parts of Brazil. In 1970, the rural population in Piranga and São Miguel do Anta corresponded to $82 \%$ and $71.6 \%$ of the populations, respectively. By 2010 , this proportion dropped to $65.4 \%$ and $44.6 \%$, respectively. Nevertheless, if the rural population had a tendency to decrease over the previous five decades, the populations of both municipalities began to increase again from the 1990s onward, precisely during the period when social security benefits were expanded in the rural environment. This fact has been pointed out in other studies such as BELTRÃO et al. (2005), who realized the income of rural benefits played an important role in reducing poverty, improving income distribution and also developing the economic dynamics in small municipalities. Therefore, it is reasonable to consider that the recovery in the number of inhabitants in municipalities with agricultural economies, such as Piranga and São Miguel do Anta, from the 1990s onward can be influenced by rural social security benefits, which were universalized for field workers in this decade.

Four types of social security benefits received by the interviewees were identified, being old age benefits the most commonly accessed by the rural elderly. The retirement benefits also included pensions for widows/widowers, pensions received because of children death and because of invalidity. Regarding the incomes of retired interviewees in both municipalities, it was reported that $82 \%$ of families with rural retirees had incomes equivalent to double the minimum salary and $73 \%$ of these families did not have more than three members.

Results indicated the existence of elderly couples living alone after their children's migration, as well as widowed elderly people-typically women 
widowed after the death of their husbands. In Piranga and São Miguel do Anta widows represent more than $80 \%$ of retirees. Thus, phenomenon of elderly population feminization was observed similar to what was reported by CAMARANO (2002). This phenomenon represents an apparent contradiction regarding the countryside masculinization observed in other studies, including a study by FROEHLICH et al. (2011), who reported the migration of women from the rural areas to the city. However, this contradiction is misleading since the phenomenon observed in the present article is related to the fact that elderly women live longer than elderly men and both groups are less affected by the migration phenomenon.

Data review that social security benefits were clearly applied to investments in home improvements and changes in lifestyle due to the phenomenon of rural pension feminization. Retired women interviews highlighted how the certainty of receiving a monthly pension benefit allows the planned acquisition of goods paid in installments. Therefore, they were gradually able to obtain home appliances and furniture they desired, planning subsequent improvements to be made in their houses. As observed by SOUZA (2006), the elderly life habitus is transformed by receiving a rural retirement income, pushing them closer to secondary habitus through the institutionalization of social security habitus in their lives. Receiving the benefit provided access to money, and this becomes a mediator for the incorporation of living standards closer to those of urban population as pointed out by REIS et al. (2015).

Devices acquisition and other investments in the house are not related just to the connection between improvements and the feminization of rural pensions. This also confirmed the development of practices based on future actions planning. These projects are focused mainly on home improvements or new houses construction.

The investment of pension benefits into household refurbishment and devices reveals a concern in improving quality of life as pointed out by REIS et al. (2015). The importance given to accommodation improvements, which was apparent among women, was not restricted only to the physical structure of their houses but extended to the acquisition of household appliances and furniture. As showed in table 1, TV, TV antenna, a simple washing machine, fridge, stove, land and mobile phone are between the most common acquisitions using the social security benefits, although some of them were acquired before the retirement.
Data from table 1 demonstrate the money received in retirement was responsible for the introduction of practices such as acquisition of durable goods and planning of family future projects. However, it is important to highlight the significance of the seasonal agricultural monetarization that is responsible for the incoming before the retirements had occurred. This phenomenon was more clearly observed in São Miguel do Anta due to the highest impact of incomes originated by coffee plantation since this activity is more prominent there. Therefore, as shown in table 1, the purchase of durable goods is lower in this municipality, which can be explained by the economic difficulties faced by coffee growers (coffee-selling prices, hard agricultural activity that limits work for elderly people and climate). Thus, the amount of durable goods purchased is not larger because receiving the retirement payment creates a regular monetarization of the farmer's work.

The evolution of house income per person in the municipalities of Piranga and São Miguel do Anta in 1991 showed an increasing in the income per person up to the year 2010. In 1991, the respective per capita incomes of Piranga and São Miguel do Anta were $\mathrm{R} \$ 89.95$ and $\mathrm{R} \$ 133.28$, corresponding to US\$107.08 and US\$158.66, respectively. For the same cities, in 2010, the respective incomes were $\mathrm{R} \$ 305.73$ and $\mathrm{R} \$ 370.37$, corresponding to US\$171.85 and US\$208.18, respectively. These data point to an increase in the monetarization of rural families through both decades. This is striking considering that the Brazilian currency (Real) in 1994 had a higher value than the dollar-a situation dramatically reversed in 2010. In 1994, the value of the U.S. dollar was $\mathrm{R} \$ 0.84$, and by 2010 it was more than twice this value (R\$1.779). Therefore, per capita income of rural families measured in U.S. dollars increased over the years from 1991 to 2000 , even considering the depreciation of the Brazilian currency.

It is reasonable to consider the per capita income of rural families has increased, not exclusively due to the increasing in rural retirements income but also because of the salaries of other family members with jobs in the primary, secondary and tertiary sectors. This fact was attested by the rural family composition of interviewed retirees. In Piranga, at least $43 \%$ of the families are maintained exclusively by the retiree's income, whereas in São Miguel so Anta, this percentage is approximately $39 \%$. In families where the retiree's income is not the exclusive one, there is a tendency to have more irregular incomes because of the seasonal activities developed by single and married kids. Rural retirees often support grandchildren (Table 2). 
Table 1 - Household appliances and furniture present in rural family homes with elderly retirees in Piranga and São Miguel do Anta, Minas Gerais, before and after retirement.

\begin{tabular}{|c|c|c|c|c|c|c|}
\hline \multirow{3}{*}{ Acquisition of durable goods } & \multirow{2}{*}{\multicolumn{3}{|c|}{ 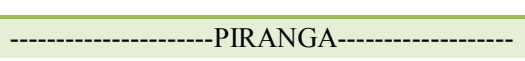 }} & & & \\
\hline & & & & \multicolumn{3}{|c|}{---------------SÃO MIGUEL DO ANTA----------- } \\
\hline & Before & AFTER & TOTAL & BEFORE & AFTER & TOTAL \\
\hline \multicolumn{7}{|l|}{ Household appliances } \\
\hline Television & 25 & 36 & 61 & 29 & 20 & 49 \\
\hline TV antenna & 21 & 40 & 61 & 26 & 24 & 50 \\
\hline Blender & 21 & 39 & 60 & 34 & 18 & 52 \\
\hline Gas stove & 27 & 31 & 58 & 29 & 22 & 51 \\
\hline Refrigerator & 24 & 32 & 56 & 29 & 21 & 50 \\
\hline Simple washing machine & 14 & 36 & 50 & 29 & 19 & 48 \\
\hline Mobile phone & 8 & 26 & 34 & 23 & 22 & 45 \\
\hline Radio & 20 & 10 & 30 & 25 & 6 & 31 \\
\hline Sound system & 16 & 13 & 29 & 17 & 7 & 24 \\
\hline Iron & 0 & 21 & 21 & 2 & 14 & 16 \\
\hline DVD & 11 & 8 & 19 & 10 & 9 & 19 \\
\hline Mixer & 11 & 2 & 13 & 17 & 3 & 20 \\
\hline Fan & 6 & 2 & 8 & 7 & 2 & 9 \\
\hline Microwave & 5 & 0 & 5 & 6 & 1 & 7 \\
\hline Washing machine & 3 & 1 & 4 & 8 & 6 & 14 \\
\hline
\end{tabular}

Source: Rural social security and changes in the lifestyles of families with retired individuals (2014).

Although the security of receiving the retirement payment does not generate consumption itself, consumption is assured because it can now be planned through investment in medium and long-term credit. Regular retirement payments make possible a predisposition for consumption of household appliances, furniture, house-building materials and vehicles supported by credit payments. Bank accounts opening to receive monthly retirement payments have educated the retired agrarians in the field of monetarization, giving rise to a new habitus for these families characterized by a predisposition to be integrated to the consumer society (Table 3 ).
Results showed that productivity has a distinct rationale. In Piranga, a productive strategy focused on self-consumption was predominant in rural families with retirees. Conversely, the strongest coffee economy in São Miguel do Anta led to an association of pension benefits to investments in production equipment and to investments into home improvements. In this sense, a higher percentage of families with bank accounts in the municipality of São Miguel do Anta support the assumption that coffee economy encourages bank transfer practices in addition to depositing pension incomes.

Table 2 - Composition of families with retirees in Piranga and São Miguel do Anta, Minas Gerais.

\begin{tabular}{|c|c|c|c|}
\hline FAMILY COMPOSITION & PIRANGA & SÃO MIGUEL DO ANTA & TOTAL \\
\hline Elderly couple living alone or widow living alone & $15(23.8 \%)$ & $16(29.6 \%)$ & $31(26.6 \%)$ \\
\hline Single elderly person or widow living alone or supporting grandchildren & $12(19.1 \%)$ & $1(9.1 \%)$ & $17(14.6 \%)$ \\
\hline Widow living with single kids and grandchildren & $22(34.8 \%)$ & $24(44.5 \%)$ & $46(39.3 \%)$ \\
\hline Elderly couple living with married kids and grandchildren & $6(9.5 \%)$ & $1(1.9 \%)$ & $7(6.0 \%)$ \\
\hline Widow living with married kids and grandchildren & $8(12.7 \%)$ & $8(14.9 \%)$ & $16(13.7 \%)$ \\
\hline TOTAL & $63(100 \%)$ & $54(100 \%)$ & $117(100 \%)$ \\
\hline
\end{tabular}


Table 3 - Socio-productive profiles of homes with retired individuals in Piranga and São Miguel do Anta, Minas Gerais.

\begin{tabular}{|c|c|c|c|}
\hline \multirow{2}{*}{ SOCIO-PRODUCTIVE PROFILES } & \multicolumn{2}{|c|}{-------------------MUNICIPALITY --------------- } & \multirow{2}{*}{ TOTAL } \\
\hline & PIRANGA & SÃO MIGUEL DO ANTA & \\
\hline Uses a mechanized machine to work the land & $17(27 \%)$ & $32(61 \%)$ & $49(43 \%)$ \\
\hline Has a Pronaf credit for production & $10(16 \%)$ & $25(47 \%)$ & $35(30 \%)$ \\
\hline Has commercialization directed to self-consumption & $46(74 \%)$ & $23(45 \%)$ & $69(60 \%)$ \\
\hline Has a bank account & $20(33 \%)$ & $31(61 \%)$ & $51(46 \%)$ \\
\hline Engages in agricultural, dairy, and meat production activities & $36(59 \%)$ & $38(73 \%)$ & $74(66 \%)$ \\
\hline Engages in only agricultural activity & $25(41 \%)$ & $14(27 \%)$ & $39(34 \%)$ \\
\hline
\end{tabular}

Source: Rural social security and changes in the lifestyles of families with retired individuals (2014).

\section{CONCLUSION}

This article showed that social security habitus becoming a routine in rural families with retirees strengthens a social view focused on investment planning and longterm acquisitions that supersedes the rustic habitus, which was focused on solving immediate problems. Rural elderly has started to acquire durable consumer goods or to substitute old models with new ones using their social security income. Other income sources such as the ones earned in coffee plantation in São Miguel do Anta contributes to the acquisition of goods before the elderly had retired. Although, the value of per capita income in the municipalities is under the minimum salary, this article showed that retirement payments are invested in durable consumer goods. Increasing in post-retirement number of durable goods acquisition evidences this fact. Finally, the security provided by receiving the monthly pension in municipalities such as Piranga and São Miguel do Anta has contributed to an approximate levelling out between rural and urban lifestyles in these small municipalities with predominantly agricultural economies.

\section{BIOETHICS AND BIOSSECURITY COMMITTE APPROVAL}

The Research Ethics Committees authorized this research for Human Beings of the Universidade Federal de Viçosa (CEP-UFV) under Opinion Number 272.141.

\section{REFERENCES}

BELTRÃO, K.I. et al. Mudanças nas condições de vida dos idosos rurais brasileiros: resultados não esperados dos avanços da seguridade rural. Rio de Janeiro: IPEA, 2005. Total de p.36.

BOLFARINE, H.; BUSSAB, W.O. Elementos de amostragem. São Paulo: Edgar Blücher, 2005. Total de p.290.

BOURDIEU, P. Le sens pratique. Paris: Minuit, 1980. Total de p. 480.

. O poder simbólico. Rio de Janeiro: Bertrand Brasil, 2008. Total dep.322.
BRUMER, A. Previdência social rural e gênero. Sociologias, Porto Alegre, v.4, n.7, p.50-81, 2002. Available from: $<$ http://www.scielo. $\mathrm{br} / \mathrm{scielo} . \mathrm{php}$ ? $\mathrm{pid}=\mathrm{S} 1517-45222002000100003 \& \mathrm{script}=\mathrm{sci}$ abstract\&tlng $=\mathrm{pt}>$. Accessed: May 2015.doi: 10.1590/S151745222002000100003

CAMARANO, A. A. Envelhecimento da população brasileira: uma contribuição demográfica. Rio de Janeiro: IPEA, 2002. Total de p. 31 .

CANDIDO, A. Os parceiros do Rio Bonito. Estudo sobre o caipira paulista e a transformação dos seus meios de vida. Rio de Janeiro: José Olympio, 2003. Total de p.336.

DELGADO, G; CARDOSO Jr., J.C. Principais resultados da pesquisa domiciliar sobre a previdência rural na região sul do Brasil (Projeto Avaliação Socioeconômica da Previdência Social Rural). Rio de Janeiro: IPEA, 2000. Total de p.63.

DUBAR, C. A socialização como incorporação do habitus. In: DUBAR, C. (Org.). A socialização: construção das identidades sociais e profissionais. São Paulo: Martins Fontes, 2005. p.77-95.

IBGE (Brasil). Censo Demográfico: 1970; 1980; 1991; 2000; 2010. Available from: <http://biblioteca.ibge.gov.br/>. Accessed: May 2015.

FIÚZA, A.L.C. et al. The way of life of pluriactivity farmers in Minho villages in Northwest Portugal. Ciência Rural, Santa Maria, v.44, p.22792285, 2014. Available from: $<$ http://www.scielo.br/scielo.php?script=sci arttext\&pid=S0103-84782014001202279>. Accessed: May 2015. doi: $10.1590 / 0103-8478 \mathrm{cr} 20131580$.

FROEHLICH, J.M. et al. Selective exodus, masculinization and rural aging in the central Region of the RS. Ciencia Rural, Santa Maria, v.41, n.9, p.1674-1680, 2001. Available from: <http://www.scielo.br/ scielo.php?script=sci_arttext\&pid=S0103-84782011000900030 $>$. Accessed: May 2015. doi: 10.1590/S0103-84782011005000124.

REIS, P.R.C. et al. Impact of Retirements and Pensions on the Social Welfare of the Households from Minas Gerais State. Revista Contabilidade \& Finanças - USP, São Paulo, v.26, n.67, p.106-118, 2015. Available from: <http://www.scielo.br/scielo.php?script=sci arttext\&pid=S1519-70772015000100106\&lng=pt\&nrm=iso\&tlng= en>. Accessed: May 2015. doi: 10.1590/1808-057x201511890.

SOUZA, J. A gramática social da desigualdade brasileira. In: SOUZA, J. A invisibilidade da desigualdade brasileira. Belo Horizonte: UFMG, 2006. p.23-54.

Ciência Rural, v.47, n.6, 2017. 